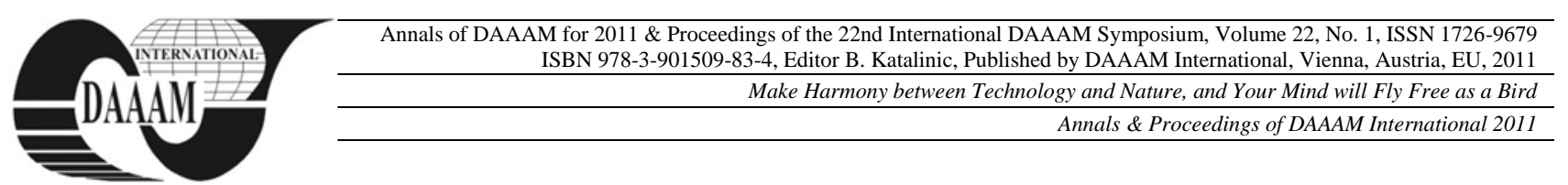

\title{
NEW WAYS IN THE MARKETING COMMUNICATION
}

\author{
CERNA, L[ubica] \& VANA, K[amil]
}

\begin{abstract}
In these days companies try to find new approach customers and gained competitive advantage in the world markets. This papre briefly deals with descriptions of non traditional and new forms of marketing communication. Nowadays the marketing become essential part of company management mainly in the globalise markets we need search for new forms and ways how to approach to the customers. The company mainly use Above The Line marketing communication but in this day we can focus on Below The Line marketing communication.
\end{abstract}

Key words: marketing communication, BTL marketing communication, ATL marketing communication, guerilla marketing

\section{INTRODUCTION}

Marketing communication and methods of marketing communication connect demand with supply. Who wants to attract and sustain customers have to do integrated marketing communication. On the base of changes in marketing communication we can recognize development of marketing communication from traditional ways to the non traditional and new ways of marketing communication and innovation in the communication mix. In present days in the global market fulfil with strong brands only the companies which are able to find competitive advantage and offer the different emotions via marketing communication are able to attract and sustain customers and be successful. This goals company can achieve via using of new tools of marketing communication or revitalization of old tools and at least launching of non traditional communication media.

The terms 'below-the-line' marketing communications refers to forms of non-media communication, even non-media advertising. Ways of non-media marketing communication are exhibitions, sponsorship activities, public relations and sales promotions. Below-the-line marketing communication is increasing important within the communications mix of many companies, not only those involved in FMCG (fast moving consumer goods) products, but also for industrial goods. Below the line marketing communication in the industrial companies in the Slovak Republic have relatively little history.

We can exemplify several features of below the line marketing communication tools:

high level of newness,

using of tool for individual communication

utilization for specific target group,

ability of straight focus on the target group,

discontinuity.

In the integrated marketing communication the marketing communication is not divided for below the and above the line marketing communication or traditional and non traditional marketing communication tools because borders between these tools in present days have thin line of border. Just because this reason is important integrate these concepts and evoke positive attitude form the side of customers and empower the brand and market position.
The new ways or non tradition ways and tools of communication are not non traditional forever, because also the tools of marketing communication are in the life cycle. During the development of new way communication tools was this tools used in the several companies and afterwards were launched in the progressive market and started used by the more and more companies. The competitive situation arises, when competitors use communication tools in the same way, this communication tool became known communication tool.

As standard ways of marketing communication in the field of marketing communication, we can define tools, which are used with almost all companies in the certain marketing and this marketing communication tools became standard part of company marketing mix. The definition of tradition or non traditional ways of marketing communication we can use only in the certain market segment. In the German companies is marketing budget divided $60 \%$ for above the line marketing communication forms and $40 \%$ for below the line marketing communication forms. In the USA is the share of below the line marketing communication forms in the marketing budget more than 70\%. In the year 2007 agency Mather realized very interesting research of trends of using advertising media among more than 300 marketing directors in the important companies in the Czech Republic market. 65 percent of the Marketing managers claimed that above the line marketing communication will be used continues (print, radio, TV, OOH - Out Of home advertising) but in the other hand majority claim, that bigger part of marketing communication will be in direct form and direct communication with target group and will be us new advertising tools.

\section{GUERILLA MARKETING}

Smaller and middle companies, which are not able to allocate money for marketing budget try to find new approach to the marketing communication, which is not so expensive and is more effective like above the line marketing communication. One way of the marketing communication which is not so expensive is guerrilla marketing.

Guerrilla marketing in his core is not new tool of marketing communication. The idea of minimize of marketing budget and maximize of effect of the marketing campaign is not new approach. Different is launching in the practise.

For a founder of Guerrilla Marketing we can consider Jay Conrad Levinson with his work Guerrilla Marketing: Secrets for Making big Profits from your Small. Levinson defined guerrilla marketing as inventional and no tradition way of advertising with low budget.

Guerrilla marketing we can apply in the siutiation where we need new approach to the customers and where we need attract attention of the customers. The guerrilla marketing is not only the advertising. Guerrilla marketing we can use in the different tools of marketing communication. Only feature of the guerrilla marketing is low budget and uniqueness. Goal of sensation marketing is fascinated audience. We offer to audience surprise or unusual and strange experience, where is advertising not as 
disturbing element and it is the experience which leaves huge impression.

\section{AMBUSH MARKETING}

Ambush marketing we can define like “... practice via other company, mostly the competitor, which try to create event with aid other company, possibly attracts attention on himself, therefore another sponsors. " [Frey, P.]

Ambush marketing is mostly classify as o certain form of Guerrilla Marketing.

Very successful marketing campaign realized by ambush marketing was done at Olympic games at Athens in the year 1999. Company NIKE really good promoted their logo and brand. TV companies from over the world take logo on flags which have people in the crowds of fans. Official sponsor of the Olympic games was REEBOK. One the reasons why is ambush marketing so popular is big interest of public in the watching of Opympic games, FIFA World Cup or ICC World Cup.

Researches defined five most using ways of ambush marketing communication strategies:

1. Sponsorship of media transmission of sport event

2. Sponsorship of the one part of the sport event

3. Sponsorship subscription

4. Intensive advertising campaign of competitors during the event

5. Other strategies.

\section{AMBIENT MEDIA MARKETING}

Expression Ambient Marketing appears in the media world around the year 1999. In the present is this expression used as standard word in the marketing management world. It is the new line of Out-Of-Home products or services, which are used as non traditional or alternative marketing media. Ambient advertising is used in combination with mainstream medias. Growth in the using of Ambient marketing media is related with decreasing of using tradition forms of marketing communication tools. In the other hand using of Point-Of-Sale communication tools has increasing trend. Other big advantage of this medium is straight focus on target group of customers. Effectiveness of ambient advertising is in the performance of this tool, the advertising massage is delivered straight to the customer and the advertising is more visible and much catchier in the minds of customers. The ambient marketing tools are able to attach attention of the crowds and evoke interaction with customers during the every day life. Good examples of ambient advertising are LCD monitors in trams, ambilights in the streets and also the other advertising in the trams.

\section{EVENT MARKETING}

In the present days during the ordinary communication we can recognize expression event, which is use for public meeting of the people. Event is more that meeting of the people on the creation pace. Marketing events are unique experience for audience and brings advertising message. From this point of view is necessary understand methods and goals of the marketing event from the side of the company.

First definition of the event marketing we can find in the middle of nineties years last century. "Event is connected with happening, experience, occurrence and performance. Simplify we can understand event as something strange, as an experience perceive by senses. Event marketing is focused on attractive production of the experience. These experience have to assignment evoke psychical and emotional incentives, are made for supporting of company image or product. Each performance we can not consider as e event, and event is not event marketing. " [Heskova, M. - Štarchon, P.]
Sistenich understand under the expression event production of occurrence in the form of emotion and experience oriented on company or the products, which are able to supply for clients emotional and visual experiences.

\section{BUZZ MARKETING}

Buzz marketing we can define or describe like Word-ofMouth Marketing (WOMM), Buzz marketing is type advertising spreading via verbal communication among people. The core of ambush marketing is conversations of people which are based on advertising or commercial information in the communication. This type of communication has added value of credibility of information. Researches prove that people are predisposed believe to information or advertising message promoted by this tool of marketing communication like other form of advertising. Listeners think that people in the communication telling truth and they have opinion, that the communication is true.

From the several agencies feedbacks and researches is clear that mouth to mouth communication have positive effect on the acceptance of the advertising message or acceptance of the certain product. The trend in the buzz marketing communication is involving of positive information about product in the conversation of two or more people at the public place. On the one hand marketing managers can use this new tool of marketing and communication and promotion to launching of the product in the marketing, but in the other they have to consider consequences from the delusiveness information share in the public because companies can be penalized for this form of campaign.

\section{CONCLUSION}

Behaviour of customers was changed during the last ten years. Prognoses to the feature are telling about changing preferences and behaviour of the customers. The importance of marketing communication and utilization of new ideas and non traditional media, media channels are increasing not only in the world but also in the Slovak market. The lifestyle is changing and purchasing and shipping habits are changing as well. In the area of marketing communication are in these days visible differences between effectiveness of traditional form of marketing media. Classic forms of marketing communication are declining.

\section{REFERENCES}

Agafonová, M. - Hrehová, D. (2009). Business ethics in the company - comparative advantage in the market, Moderné prístupy k manažmentu podniku, ISBN 978-80-2273-169-0, Bratislava

Frey, P. (2005). Marketing Communication, new ternds and their application, Marketingová komunikace. Nové trendy a jejich využití, Management Press, ISBN 80-7261-129-1, Praha

Heskova, M. - Štarchon, P. (2009). Event marketing the sport programs, Event marketing a jeho uplatnení v turistických a sportovních programech, In: Management a marketing sportu a cestovního ruchu. Západočeská univerzita v Plzni, 2009, ISBN 978-80-7043-801-5, Plzeň

Kotler, Ph. (1998), Marketing management. Praha: Grada Publishing, 1998, 712 s. ISBN 80-7169-600-5, Praha

Prekopová, P. (2009). Social responsibylitly as a tool of marketing, Je spoločenská zodpovednost' d’alším nástrojom marketingu In: Manažment podnikania a vecí verejných, Slovenská akadémia manažmentu, ISBN 1337-0510, Bratislava 